\title{
Analisis Segmentasi Pelanggan Menggunakan Kombinasi RFM Model dan Teknik Clustering
}

\author{
Beta Estri Adiana $^{1}$, Indah Soesanti ${ }^{2}$, Adhistya Erna Permanasari ${ }^{3}$ \\ Jurusan Teknik Elektro dan Teknologi Informasi, Universitas Gadjah Mada \\ Jl. Grafika No.2, Yogyakarta \\ beta.estri.a@mail.ugm.ac.id \\ Jurusan Teknik Elektro dan Teknologi Informasi, Universitas Gadjah Mada \\ Jl. Grafika No.2, Yogyakarta \\ indsantiegmail.com \\ Jurusan Teknik Elektro dan Teknologi Informasi, Universitas Gadjah Mada \\ Jl. Grafika No.2, Yogyakarta \\ adhistya@ugm.ac.id
}

\begin{abstract}
Intense competition in the business field motivates a small and medium enterprises (SMEs) to manage customer services to the maximal. Improve of customer royalty by grouping cunstomers into some of groups and determining appropriate and effective marketing strategies for each group. Customer segmentation can be performed by data mining approach with clustering method. The main purpose of this paper is customer segmentation and measure their loyalty to a SME's product. Using CRISP-DM method which consist of six phases, namely business understanding, data understanding, data preparation, modeling, evaluation and deployment. The K-Means algorithm is used for cluster formation and RapidMiner as a tool used to evaluate the result of clusters. Cluster formation is based on RFM (recency, frequency, monetary) analysis. Davies Bouldin Index (DBI) is used to find the optimal number of clusters $(k)$. The customers are divided into 3 clusters, total of customer in first cluster is 30 customers who entered in typical customer category, the second cluster there are 8 customers who entered in superstar customer and 89 customers in third cluster is dormant cluster category.
\end{abstract}

Keywords - customer segmentation, data mining, clustering, CRISP-DM, RFM model, K-Means algorithm.

Intisari - Persaingan yang ketat di bidang bisnis memotivasi sebuah usaha kecil dan menengah (UKM) untuk mengelola pelayanan terhadap konsumen tetap (pelanggan) secara maksimal. Meningkatkan kesetiaan pelanggan dengan mengelompokkan pelanggan menjadi beberapa kelompok dan menentukan strategi pemasaran yang tepat dan efektif untuk setiap kelompok. Segmentasi pelanggan dapat dilakukan melalui pendekatan data mining dengan metode clustering. Tujuan utamanya adalah segmentasi pelanggan dan mengukur kesetiaan mereka terhadap sebuah produk UKM. Dengan menggunakan metode CRISP-DM yang terdiri dari enam fase, yakni pemahaman bisnis (business understanding), pemahaman data (data understanding), persiapan data (data preparation), pemodelan (modeling), evaluasi (evaluation), dan penerapan (deployment). Algoritma K-means digunakan untuk pembentukan klaster dan RapidMiner sebagai tool yang digunakan untuk mengevaluasi klaster-klaster yang terbentuk. Pembentukan klaster didasarkan pada analisa RFM ( Recency,
Frequency, dan Monetary). Davies Bouldin Index (DBI) digunakan untuk menemukan jumlah cluster (k) yang optimal. Hasilnya kelompok pelanggan yang terbentuk ada tiga kelompok dengan kelompok pertama berjumlah 30 pelanggan masuk dalam kategori typical customer, kelompok kedua terdapat 8 pelanggan yang masuk dalam kategori superstar customer dan kelompok ketiga berjumlah 89 pelanggan pada kategori dormant customer.

Kata Kunci - segmentasi pelanggan, data mining, clustering, CRISP-DM, model RFM, algoritma K-Means.

\section{Pendahuluan}

Sejalan dengan peradaban manusia mempengaruhi perkembagan teknologi informasi (TI). Perkembangan TI mempengaruhi beberapa sektor, seperti di bidang bisnis, bidang kesehatan, bidang pendidikan, dan juga pemerintahan. Dalam persaingan bisnis, perusahaan dituntut untuk dapat memanfaatkan kemampuan yang ada semaksimal mungkin agar mampu bersaing dengan perusahaan lain.

Perubahan kebutuhan pelanggan mendorong terjadinya perubahan dalam bidang pemasaran. Bagian pemasaran perusahaan memiliki peran penting dalam menghadapi persaingan yang semakin ketat dengan perusahaan lain. Perusahaan yang berorientasi pasar atau dengan kata lain menjual produk ke pelanggan, umumnya akan menghadapi masalah di bidang pemasaran. Diperlukan survei pasar untuk mendapatkan informasi tentang permintaan dan kebutuhan spesifik pelanggan [1]. Perusahaan harus mempertimbangkan karakteristik setiap pelanggan. Informasi itu digunakan untuk mengembangkan produk yang mengandung kombinasi dan atribut optimal yang diinginkan oleh pelanggan.

Saat ini, perusahaan modern tidak hanya fokus pada strategi yang mengutamakan produk (product/service oriented), mereka juga melakukan strategi yang 
mengutamakan pelanggan (customer oriented). Hal ini penting dilakukan untuk perkembangan perusahaan dengan menciptakan hubungan baik antara perusahaan dan pelanggan [2][3]. Situasi ekonomi masyarakat yang semakin berubah, dengan persaingan industri pangan yang semakin ketat, ditandai dengan meningkatnya jumlah produk serupa yang ditawarkan kepada pelanggan. Teknologi informasi menjadi sangat berpengaruh bagi kemajuan sebuah industri. Teknologi informasi membantu memberikan layanan atau produk yang lebih baik kepada pelanggan [4].

UD Gemilang Kencana merupakan salah satu usaha kecil dan menengah (UKM) di Kabupaten Wonosobo yang bergerak di bidang industri makanan pengolahan buah Carica menjadi manisan. Industri ini menyadari akan pentingnya hubungan antara pelanggan yang loyal dengan keberhasilan bisnis. UD Gemilang Kencana setiap harinya harus memenuhi kebutuhan konsumen dan dituntut untuk dapat mengambil keputusan yang tepat dalam menentukan strategi penjualan. Konsumen yang datang dari berbagai kalangan dengan selera yang berbeda, menuntut industri ini harus mampu menarik minat beli konsumen. Dengan jumlah konsumen yang tergolong banyak dan terus meningkat mengakibatkan UD Gemilang Kencana kesulitan mengidentifikasi minat beli konsumen dan selera konsumen terhadap produknya. Penggunaan metode manual atau tradisional untuk melakukan identifikasi konsumen dari data membutuhkan kemampuan manusia untuk menganalisis dan mengintepretasikan data. Dengan volume data yang berkembang, baik dari jumlah record dan jumlah field. Hal ini dapat mengakibatkan UD Gemilang Kencana kehilangan konsumen potensial dan merugikan perusahaan.

Segmentasi pelanggan diperlukan untuk mengelompokkan pelanggan yang memiliki kesamaan karakteristik. Hal ini diperlukan untuk mengetahui perilaku (behavior) konsumen sehingga akan membantu dalam penerapan strategi pemasaran (marketing) yang tepat untuk meningkatkan pendapatan perusahaan. Penggunaan teknik data mining merupakan salah satu solusi untuk persoalan segmentasi konsumen. Data mining diharapkan dapat membantu proses pengambilan keputusan yang tepat, memungkinkan perusahaan atau industri untuk mengelola data yang tersimpan dalam suatu basis data, data warehouse, atau tempat penyimpanan lainnya menjadi sebuah informasi dan pengetahuan (knowledge) yang baru. Data mining dapat mengekstrak pengetahuan berharga dari sejumlah data yang diatur oleh pemahaman manusia [5] sehingga pengembangan aplikasi data mining penting untuk pengembangan bisnis.

Clustering merupakan teknik data mining yang membagi data dalam suatu himpunan ke dalam beberapa kelompok yang mana kesamaan data dalam suatu kelompok lebih besar dibandingkan kesamaan data tersebut dengan data dalam kelompok lain [6]. Semakin kecil jumlah cluster yang digunakan, maka akan mempermudah pemahaman terhadap struktur data di dalamnya, tetapi pola informasi penting yang ada akan terabaikan. Sebaliknya dengan memberikan jumlah cluster akhir yang lebih besar, maka kesamaan yang dimiliki antar kelompok akan semakin meningkat pula dan mengabaikan struktur data yang ada [7].

Salah satu metode clustering yang sangat populer dan banyak dipelajari untuk meminimalkan kesalahan clustering untuk titik ruang Euclidean disebut K-Means clustering [8]. Pendekatan K-Means termasuk dalam tipe partisi dalam clustering [8][9][10]. Pendekatan K-Means mengambil strategi greedy (serakah) yang menghasilkan partisi baru dengan menugaskan setiap pola ke pusat klaster terdekat dan menghitung pusat klaster baru [11]. K-Means mengklasifikasi data tertentu yang ditetapkan melalu sejumlah klaster (k cluster). Idenya adalah mendefinisikan nilai pusat k (k centroid), satu untuk setiap klaster. Nilai pusat ini harus ditempatkan dengan pintar karena lokasi yang berbeda menyebabkan hasil yang berbeda. Penelitian ini dilakukan untuk segmentasi pelanggan untuk membantu menganalisis data transaksi pada industri makanan, dikembangkan menggunakan metode K-Means dan model RFM. Model RFM merupakan model yang membedakan pelanggan penting dari data besar oleh tiga variabel yaitu recency, frequency dan monetary. Perangkat lunak yang digunakan untuk melakukan penelitian ini adalah Microsoft Excel untuk penyimpanan data dan RapidMiner sebagai perangkat lunak untuk mengevaluasi. Kombinasi antara model RFM dan metode K-Means mampu membantu dalam proses pengelompokkan setiap kategori pelanggan dan mengetahui tingkat loyalitas yang dimilikinya.

\section{LANDASAN TEORI}

\section{A. Model RFM}

Model RFM (Recency, Frequency dan Monetary) telah banyak diterapkan dalam beberapa bidang, terutama dalam dunia pemasaran. Dengan mengadopsi model RFM, seorang pengambil keputusan dapat secara efektif mengidentifikasi pelanggan yang berharga dan akan digunakan sebagai pengembangan strategi pemasaran yang efektif [12]. Model RFM sering digunakan untuk segmentasi pasar. RFM mempertahankan informasi tentang waktu pembelian (recency) paling akhir, berapa kali pelanggan melakukan pembelian (frequency), dan rata-rata uang yang dihabiskan (monetary) [13]. Pelanggan yang telah membeli baru-baru ini, paling sering, dan menghabiskan banyak uang berpeluang untuk bereaksi terhadap promosi di waktu yang akan datang [14]. Keuntungan model RFM terletak pada relevansinya selama beroperasi pada beberapa variabel yang dapat diamati dan bersifat obyektif. Variabel ini 
digolongkan menurut 3 kriteria, yaitu recency, frequency, dan monetary. Recency merupakan interval waktu antara pembelian terakhir dengan waktu sekarang, nilai yang lebih rendah sesuai dengan probabilitas yang lebih tinggi bahwa pelanggan akan melakukan pembelian ulang. Frequency adalah jumlah transaksi yang telah dilakukan pelanggan dalam jangka waktu tertentu dan monetary adalah jumlah uang yang dihabiskan dalam periode waktu yang ditentukan [15].

Penelitian yang dilakukan oleh Ait Daoud et al., [16] menggunakan variabel behavioral, recency, frequency dan monetary yang didapatkan menggunakan model RFM, kemudian disegmentasi menggunakan metode clustering. Hasilnya dari 730 pelanggan terbagi menjadi 8 cluster, 7 cluster menjadi kelompok terpenting untuk penerapan strategi pemasaran di masa depan. Pada kesimpulan, penulis menuliskan bahwa model RFM dan teknik clustering yang diterapkan pada online shop dapat membantu mengidentifikasi pelanggan dengan high-value dan potensi keuntungan dan kemudian mendesain strategi pemasaran yang berbeda untuk setiap cluster yang terbentuk. Analisis RFM merupakan alat sederhana dan ampuh untuk menganalisis perilaku pelanggan. Meluasnya perdagangan melalui internet memudahkan pengumpulan riwayat pembelian dan pelacakan perilaku belanja pelanggan. Persaingan yang semakin ketat membuat pemahaman terhadap perilaku pelanggan menjadi kunci sukses sebagai masyarakat informasi [13].

Nilai recency, frequency, dan monetary dibagi menjadi lima bagian dengan nilai 1, 2, 3, 2, dan 5. Nilai recency dihitung berdasarkan tanggal transaksi terakhir atau interval waktu transaksi terakhir dengan saat ini. Nilai 5 diberikan kepada pelanggan dengan tanggal transaksi terbaru dan nilai 1 untuk pelanggan dengan tanggal transaksi terjauh di masa lalu. Kemudian frequency, pelanggan yang sering bertransaksi mempunyai nilai 5, sedangkan pelanggan yang jarang bertransaksi mempunyai nilai 1. Pelanggan yang membelanjakan banyak uang untuk melakukan transaksi mempunyai nilai monetary yang tinggi, yaitu nilai 5 . Sedangkan pelanggan yang sedikit mengeluarkan uang mempunyai nilai monetary yang rendah, yaitu nilai 1 [17] [18]. Berikut merupakan perhitungan skor RFM:

$$
\begin{aligned}
\text { skor } R F M=(( & \text { nilai recency } x 100) \\
& +(\text { nilai frequency } x 0) \\
& + \text { nilai monetary }
\end{aligned}
$$

\section{B. Data Mining}

Data mining merupakan salah satu bagian langkah penting dalam proses KDD (Knowledge Discovery in
Database) terutama berkaitan dengan ekstraksi dan perhitungan pola-pola yang ditelaah.

CRISP-DM (Cross Industry Standard Process for Data Mining) merupakan standar proses data mining yang ditujukan untuk melakukan proses analisis dari suatu industri sebagai dasar strategi pemecahan masalah dari bisnis atau unit penelitian [17]. Gambar 1 menunjukkan siklus proses CRISP-DM.

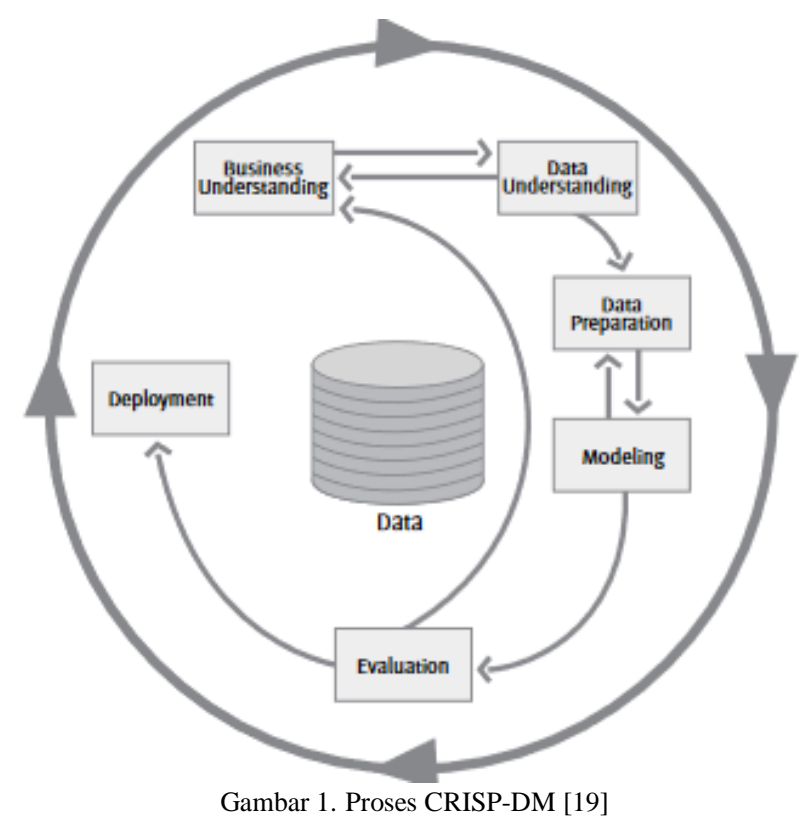

Berikut merupakan 6 fase CRISP-DM [19] :

1) Business understanding (pemahaman bisnis): Tahap pertama adalah memahami tujuan dan kebutuhan dari sudut pandang bisnis, kemudian menterjemahkan pengetahuan ini ke dalam pendefinisian masalah dalam data mining. Selanjutnya akan ditentukan rencana dan strategi untuk mencapai tujuan tersebut.

2) Data understanding (pemahaman data): Tahap ini dimulai dengan pengumpulan data yang kemudian akan dilanjutkan dengan proses untuk mendapatkan pemahaman yang mendalam tentang data, mengidentifikasi masalah kualitas data, atau untuk mendeteksi adanya bagian yang menarik dari data yang dapat digunakan untuk hipotesa untuk informasi yang tersembunyi.

3) Data preparation (persiapan data): Tahap ini meliputi kegiatan untuk membangun kumpulan data akhir (data yang akan diproses pada tahap pemodelan) dari data mentah. Tahap ini dapat diulang beberapa kali. Pada tahap ini juga mencakup pemilihan tabel, record, dan atribut-atribut data, termasuk proses pembersihan dan transformasi data untuk kemudian dijadikan masukan dalam tahap pemodelan

4) Modeling (pemodelan): Dalam tahap ini akan dilakukan pemilihan dan penerapan berbagai teknik pemodelan dan beberapa parameternya akan disesuaikan untuk mendapatkan nilai yang optimal. Secara khusus, ada 
beberapa teknik berbeda yang dapat diterapkan untuk masalah data mining yang sama. Di pihak lain ada teknik pemodelan yang membutuhkan format khusus sehingga pada tahap ini masih memungkinkan kembali ke tahap sebelumnya.

5) Evaluation (evaluasi): Pada tahap ini, model sudah terbentuk dan diharapkan memiliki kualitas baik jika dilihat dari sudut pandang analisis data. Pada tahap ini akan dilakukan evaluasi terhadap apakah model dapat mencapai tujuan yang ditetapkan pada fase awal (pemahaman data). Kunci dari tahap ini adalah menentukan ada atau tidak masalah bisnis yang dipertimbangkan. Pada akhir dari tahap ini harus ditentukan penggunaan hasil proses data mining.

6) Deployment (pengembangan): Pada tahap terakhir, pengetahuan atau informasi yang telah diperoleh akan diatur dan dipresentasikan dalam bentuk khusus sehingga dapat digunakan oleh pengguna. Tahap pengembangan dapat berupa pembuatan laporan sederhana atau mengimplementasikan proses data mining yang berulang dalam perusahaan. Dalam banyak kasus, tahap deployment melibatkan konsumen, di samping analis data, karena sangat penting bagi konsumen untuk memahami tindakan yang harus dilakukan menggunakan model yang telah dibuat.

Referensi [20] mengadopsi metodologi CRISP-DM untuk memprediksi fase pengobatan gangguan pada ibu hamil di Julio Dinis Maternity Hospital. Mereka menjelaskan proses yang rumit, ketika selesai dalam konteks metodologis, CRISP-DM menjadi lebih mudah dipahami, diterapkan dan dikembangkan.

CRISP-DM mengusulkan sebuah model proses yang komprehensif untuk melakukan proyek data mining. Paper yang ditulis oleh Rudiger dan Wilhelm [20], memberikan pendapat bahwa model proses standar akan bermanfaat bagi industri data mining dan menyajikan beberapa pengalaman praktis dengan metodologi CRISP-DM. Tujuannya adalah untuk menentukan suatu proses yang dapat diulang dengan andal dan efisien oleh orang yang berbeda dengan situasi yang berbeda juga. Mereka menyimpulkan bahwa CRISPDM bekerja dengan baik. Model proses generik berguna untuk perencanaan, dokumentasi dan komunikasi. Model proses cukup mudah untuk ditulis namun tingkat ketepatan yang suliy. Proyek CRISP-DM tidak mudah untuk dievaluasi, terutama dalam hal kecepatan dan biaya. Tapi CRISP-DM mendukung proses yang berulang dan sangat berguna untuk proyek yang besar.

\section{K-Means Clustering}

Teknik data mining telah diterapkan pada berbagai domain. Aktivitas transaksi pada sebuah organisasi yang terjadi hampir setiap hari, membuat data transaksi menjadi sangat banyak dan kompleks. Dengan teknik data mining, khususnya teknik clustering, dapat diterapkan untuk membagi seluruh pelanggan menjadi beberapa kelompok (cluster) berdasarkan beberapa kesamaan pada pelanggan
[21]. Clustering adalah studi formal untuk partisi atau mengelompokkan data dengan tidak menggunakan pelabelan kategori. Clustering bersifat unsupervised learning atau tidak mempunyai tahap pelatihan data, berbeda dengan klasifikasi. Clustering digunakan untuk mengelompokkan data secara alamiah berdasarkan kemiripan pada objek data dan sebaliknya meminimalkan kemiripan terhadap cluster lain [17].

Algoritma K-Means adalah algoritma klasik untuk memecahkan masalah clustering [22]. Metode K-Means merupakan metode non-hirarkis. Metode ini merupakan teknik penyekatan (partition) yang membagi atau memisahkan obyek k ke daerah yangt terpisah [6]. Metode K-Means digunakan untuk mengelompokkan $\mathrm{n}$ vector berdasarkan atribut partisi $\mathrm{k}$, dimana $\mathrm{k}<\mathrm{n}$, tergantung pada beberapa tindakan. Pusat cluster adalah mean (nilai tengah) semua vector pada cluster tertentu. Algoritma ini dimulai dengan memilih centroid $\mathrm{k}$ awal secara acak (randomly), kemudian memberikan nilai vektor ke centroid terdekat dengan Euclidean distance dan menghitung ulang centroid baru. Proses ini berulang sampai vector tidak lagi mengubah cluster antar iterasi [23].

Pengembangan implementasi data mining sangat penting untuk perusahaan telekomunikasi, yang merupakan tipe industri data-intensive. Segmentasi pelanggan akan membantu menganalisa komposisi pelanggan dengan akurat dan memajukan kualitas pelayanan dan pemasaran. Menggunakan K-Means clustering dan data mining tool KXEN, penelitian lainnya mengusulkan resolusi dari segmentasi pelanggan untuk Changzou telecom di provinsi Jiangsu. Hasil menunjukkan bahwa resolusinya efektif dan sukses [5]. Kemudian penelitian berikutnya menggunakan machine learning untuk teknik clustering yang digunakan untuk segmentasi pelanggan dari sebuah distributor. Penelitian ini menjelaskan tentang seleksi, analisis dan interpretasi cluster untuk mengevaluasi pelanggan yang menghabiskan produk setiap tahunnya. Algoritma K-Means menjadi pilihan mereka dalam mengelompokkan pelanggan melalui perilaku pelanggan [24]. Dalam penelitian ini KMeans digunakan karena komputasi yang ringan, kemudian sesuai dengan kebutuhan data yang akan di cluster, dan sesuai dengan tujuan untuk menentukan jumlah cluster di awal untuk memperoleh jumlah kelompok pelanggan yang optimal.

\section{Segmentasi Pelanggan}

Segmentasi terus menjadi konsep pemasaran yang penting juga dalam konteks relationship marketing. Meningkatkan hubungan dengan pelanggan menjadi lebih menarik dan akan menghasilkan pemahaman yang lebih baik tentang kebutuhan pelanggan. Paper ini [20] berpendapat bahwa analisis retrospektif atau historis yang memberikan fasilitas perhitungan profitabilitas customer relationship, 
merupakan titik awal yang sangat baik untuk segmentasi pelanggan. Segmentasi terbukti menjadi instrumen analisis yang kuat sebagai dasar perumusan, strategi pemasaran.

Segmentasi adalah proses membagi pelanggan menjadi beberapa klaster dengan kategori loyalitas pelanggan untuk membangun strategi pemasaran. Segmentasi pelanggan adalah salah satu langkah awal dalam membuat model bisnis. Segmentasi pelanggan dibagi menjadi 6 karakteristik berdasarkan nilai RFM seperti yang ditunjukkan pada Tabel 1 [25]:

TABEL I

KARAKTERISTIK PELANGGAN

\begin{tabular}{|c|c|}
\hline Kelas pelanggan & Karakteristik \\
\hline Superstar & $\begin{array}{ll}\text { a. } & \text { Pelanggan dengan loyalti } \\
\text { yang tinggi. } & \\
\text { b. Mempunyai nilai } & \text { monetary yang tinggi } \\
\text { c. } & \text { Mempunyai frekuensi } \\
& \text { yang tinggi } \\
\text { d. } & \text { Mempunyai transaksi } \\
& \text { paling tinggi }\end{array}$ \\
\hline Golden customer & $\begin{array}{ll}\text { a. } & \text { Mempunyai nilai } \\
& \text { monetary teringgi yang ke } \\
& \text { dua } \\
\text { b. } & \text { Frequency yang tinggi } \\
\text { c. } & \text { Mempunyai rata-rata } \\
& \text { transaksi }\end{array}$ \\
\hline Typical customer & $\begin{array}{ll}\text { Mempunyai } & \text { rata-rata nilai } \\
\text { monetary } & \text { dan rata-rata } \\
\text { transaksi } & \end{array}$ \\
\hline $\begin{array}{l}\text { Occational } \\
\text { customer }\end{array}$ & $\begin{array}{l}\text { a. Nilai monetary terendah } \\
\text { kedua setelah dormant } \\
\text { customer } \\
\text { b. Nilai recency paling } \\
\text { rendah } \\
\text { c. Transaksi paling tinggi }\end{array}$ \\
\hline Everyday shopper & $\begin{array}{l}\text { a. Memiliki peningkatan } \\
\text { transaksi } \\
\text { b. Transaksi yang rendah } \\
\text { c. Mempunyai nilai } \\
\\
\text { monetary sedang sampai } \\
\text { dengan rendah }\end{array}$ \\
\hline $\begin{array}{l}\text { Dormant } \\
\text { customer }\end{array}$ & $\begin{array}{l}\text { a. Mempunyai frequency } \\
\text { dan monetary yang paling } \\
\text { rendah } \\
\text { b. Nilai recency yang paling } \\
\text { rendah }\end{array}$ \\
\hline
\end{tabular}

\section{Metodologi Penelitian}

Cross Industry Standard Process for Data Mining (CRISP-DM) merupakan metode yang digunakan dalam penelitian ini. CRISP-DM adalah model proses penambangan data (data mining) yang sering digunakan para ahli untuk memecahkan masalah. Jalannya penelitian mengacu pada enam tahap CRISP-DM, yang meliputi proses pemahaman bisnis, pemahaman data, persiapan data, pemodelan, evaluasi, dan proses yang terakhir adalah pengembangan/penyebaran.

\section{A. Pemahaman Bisnis}

Memahami tujuan dan kebutuhan dalam lingkup bisnis atau unit penelitian, menterjemahkan pengetahuan ini ke dalam permasalahan data mining. Kemudian menentukan strategi untuk mencapai tujuan tersebut. Studi kasus penelitian ini dilakukan di salah satu UKM (Usaha Kecil dan Menengah) di Kabupaten Wonosobo yaitu UD Gemilang Kencana, sebuah usaha kecil dan menengah yang memproduksi manisan buah carica. Unit dagang ini berdiri akhir tahun 2014 dengan jumlah konsumen yang terus meningkat dari tahun ke tahun. UD Gemilang Kencana melayani transaski penjualan baik secara langsung (offline) dengan konsumen atau dengan media online seperti Whatsapp, Facebook, dan Instagram. Data transaksi yang tersimpan digunakan untuk melakukan pengelompokan atau segmentasi pelanggan UD Gemilang Kencana. Untuk mempermudah dalam proses pengelompokkan pelanggan, pada penelitian ini menggunakan parameter recency (terakhir melakukan transaksi), frequency (seringnya melukan transaksi), dan monetary (berapa banyak uang untuk transaksi). Selain itu untuk memudahkan dalam pengelompokan data dan pelabelan pelanggan, dalam penelitian ini menggunakan aplikasi RapidMiner untuk proses pengelompokan pelanggan secara otomatis dan dapat diketahui karakter masing-masing pelanggan.

\section{B. Pemahaman data}

Pada proses ini akan dilakukan pemahaman terhadap kebutuhan data terkait dengan pencapaian tujuan dalam CRM (Customer Relationship Management) dan data mining. Data diambil dari salah satu UKM di Kabupaten Wonosobo. Kemudian dilakukan pemahaman data, mengidentifikasi kualitas data, memeriksa data dan membersihkan data yang tidak valid (data cleansing). Penelitian ini menggunakan data transaksi penjualan manisan buah carica dari 1 Juni 2017 sampai dengan 31 Desember 2017. Data diambil dari dokumentasi UD Gemilang Kencana yang berformat xls. Jumlah data transkasi terdiri dari 127 data.

\section{Persiapan Data}

Pada tahap ini data yang tersimpan akan dipersiapkan sehingga mempemudah proses penambangan (mining). Ada beberapa proses yang dilakukan dapat mempersiapkan data diantaranya memilih variabel yang akan dianalisis, membersihkan data, menyiapkan data awal sehingga siap untuk data transformation. 
Segmentasi pelanggan pada penelitian ini berdasarkan pada model RFM (recency, frequency, monetary), maka data selection dari model RFM adalah rentang waktu terakhir pelanggan melakukan transaksi dengan metode analisis, jumlah frekuensi (seberapa sering) transaksi yang dilakukan pelanggan selama periode penelitian, serta jumlah nominal transaksi untuk setiap pelanggan selama periode penelitian, yaitu selama 1 Juni sampai dengan 31 Desember 2017. Tabel 2 menunjukkan hasil dari data selection.

TABEL II

HASIL SELEKSI DATA

\begin{tabular}{|l||l|}
\hline Data Awal & Data Akhir \\
\hline \hline $\begin{array}{l}\text { Tanggal terakhir transaksi } \\
\text { (tipe: date) }\end{array}$ & Recency (type: number) \\
\hline $\begin{array}{l}\text { Jumlah melakukan } \\
\text { transaksi }\end{array}$ & Frequency \\
\hline Jumlah nominal transaksi & Monetary \\
\hline
\end{tabular}

Setelah melakukan data selection, proses selanjutnya yang harus dilakukan adalah data preprocessing. Proses ini berfungsi untuk memastikan kualitas data yang telah dipilih pada tahap data selection. Pada tahap ini diperlukan adanya pembersihan data (data cleansing). Data cleansing yang dilakukan yaitu membersihkan data RFM dari noise atau missing value, dengan membuang noise atau missing value pada data. Tahap selanjutnya adalah data transformation yang dilakukan dengan cara normalisasi. Normalisasi dilakukan agar skala data tidak berbeda terlalu jauh.

\section{Pemodelan}

Adapun metode yang diusulkan pada pemodelan penelitian ini adalah algoritma K-Means. Data input untuk proses clustering yaitu data RFM transaksi pelanggan yang sudah dinormalisasi. Proses clustering meggunakan algoritma K-Means ditunjukkan oleh flowchart pada Gambar 2.

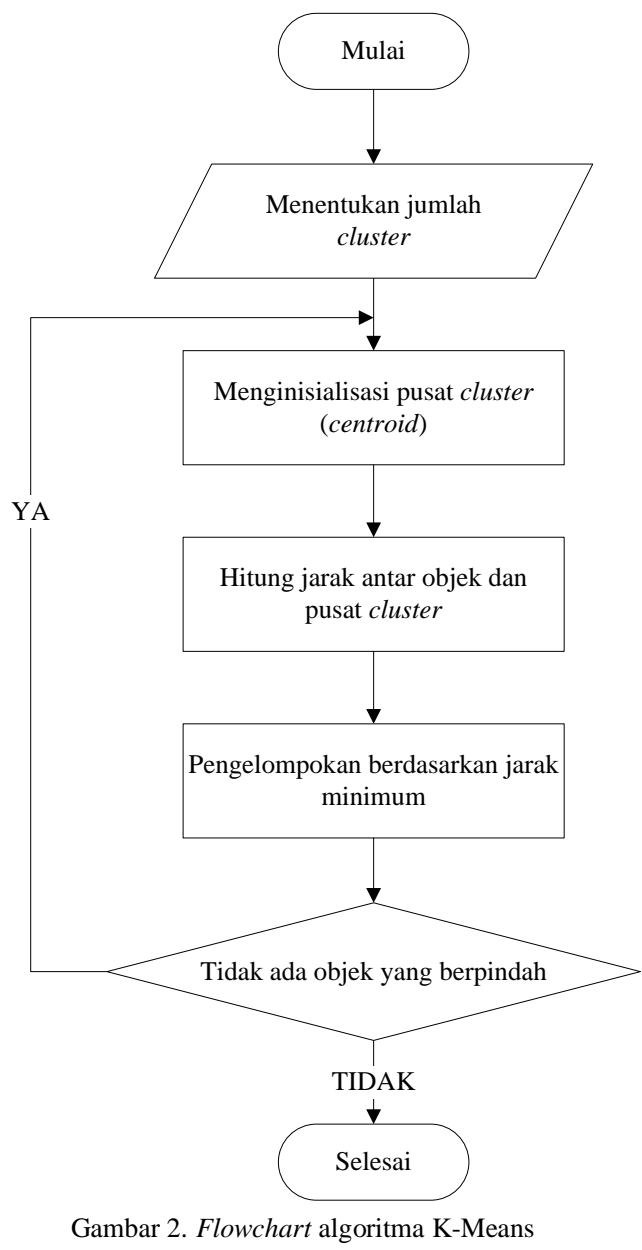

Berdasarkan konsep yang sudah dijelaskan, proses komputasi untuk K-Means dijelaskan sebagai berikut [26][27][28][29]:

1. Inisialisasi vektor centroid klaster secara acak

2. Untuk setiap data vektor, hitung jarak antar data vektor dengan masing-masing klaster centroid yang akan ditentukan vektor data minimum dengan klaster dan jarak yang dihitung menggunakan persamaan:

$$
d(Z p, M j)=\sqrt{\sum_{k=1}^{d}(Z p, k-M j, k)}
$$

Di mana $\mathrm{Zp}$ adalah titik data ke-p, $\mathrm{Mj}$ adalah centroid dari data klaster ke-j.

3. Hitung ulang klaster centroid menggunakan persamaan:

$$
M_{j}=1 / n_{j}\left(\sum Z_{p}\right)
$$

Dimana $\boldsymbol{n}_{\boldsymbol{j}}$ adalah jumlah titik data di klaster $\mathrm{j}$.

4. Ulangi langkah 3 dan 4 hingga berhenti memenuhi kriteria. Kriteria yang memuaskan dapat berupa jumlah iterasi atau perubahan posisi centroid dalam iterasi berurutan.

K-Means dipakai sebagai metode clustering pada paper ini karena kelebihanya [30], yaitu: 
1. Mudah untuk diimplementasikan

2. Kemudahan dan kecepatan komputasi sehingga memungkinkan untuk digunakan pada dataset yang besar.

Selain itu K-Means juga memiliki beberapa kekurangan yang perlu diperhatikan [28][30], yaitu:

1. Pemilihan awal jumlah cluster (k) harus diketahui dan ditentukan sebelumnya oleh pengguna.

2. Hasil terakhir bergantung pada pusat cluster awal yang dipilih secara acak.

3. Kadang mengakibatkan adanya cluster yang kosong karena tidak ada titik awal yang dialokasikan saat langkah penetapan pusat cluster awal.

\section{E. Evaluasi}

Tahap evaluasi merupakan tahap interpretasi terhadap pemodelan data mining berdasarkan domain pengetahuan pada pemahaman bisnis. Tahap evaluasi dilakukan setelah klaster-klaster terbentuk dari hasil clustering. Pada tahap ini kami mengusulkan dua proses evaluasi yakni Global Silhoutte dan Variance. Metode silhouette merupakan salah satu metode yang digunakan untuk menguji kualitas klaster yang dihasilkan dari proses clustering. Berikut merupakan persamaan yang digunakan pada global silhouette [31]:

$$
S(i)=\frac{b(i)-a(i)}{\max \{a(i), b(i)\}}
$$

Dimana:

$S(i)=$ nilai silhouette .

$b(i)=$ rata-rata jarak dari objek i dengan seluruh objek dalam cluster yang sama.

$a(i)=$ rata-rata jarak dari objek i dengan objek berada di cluster yang berbeda.

Nilai dari silhouette berkisar $-1 \leq S(i) \leq 1$, dimana hasil clustering baik jika nilai silhouette bernilai positif (0-1) [31]. Hal ini menandakan bahwa data berada pada cluster yang tepat.

Proses evaluasi yang kedua dilakukan dengan evaluasi nilai variance $(\mathrm{R})$. $\mathrm{R}$ adalah nilai rasio antara jarak rata-rata data dalam satu cluster dan jarak rata-rata dengan cluster lain. Nilai $\mathrm{R}$ yang mendekati 0 menunjukkan dalam satu cluster memiliki kemiripan nilai yang dekat [32].

$$
R=\frac{1 / c \sum_{i=1}^{C} R c}{1 / c \sum_{i, j=1}^{C} R i j}
$$

Dimana:

$\mathrm{R}$ adalah nilai variance

$\mathrm{C}$ adalah jumlah cluster

Rc adalah jarak rata-rata objek dalam satu cluster

Rij adalah jarak rata-rata objek dengan cluster lain

\section{F. Pengembangan}

Dalam tahap ini pengetahuan atau informasi yang telah diperoleh diimplementasikan dalam sebuah laporan agar lebih mudah dipahami oleh pihak yang berkepentingan .

\section{HASIL DAN PEMBAHASAN}

Data yang digunakan untuk pemodelan clustering adalah data transaksi online di UD Gemilang Kencana pada periode 1 Juni sampai dengan 31 Desember 2017. Data diambil secara manual yang dituliskan dalam Microsoft Excel. Tabel 3 merupakan data transaksi yang terdiri dari nama pelanggan, terakhir transaksi, frekuensi, dan jumlah uang yang dikeluarkan.

TABEL III

CUPLIKAN DATA TRANSAKSI PELANGGAN

\begin{tabular}{|l|c|c|r|}
\hline Nama & $\begin{array}{l}\text { Terakhir } \\
\text { transkasi }\end{array}$ & Frekuensi & Jumlah \\
\hline Adi & $6 / 5 / 2017$ & 2 & $1,554,000$ \\
\hline $\begin{array}{l}\text { Agustinus } \\
\text { Prie }\end{array}$ & $12 / 23 / 2017$ & 3 & 615,000 \\
\hline $\begin{array}{l}\text { Aisyah } \\
\text { Eliani }\end{array}$ & $6 / 10 / 2017$ & 3 & $2,205,000$ \\
\hline $\begin{array}{l}\text { Anggun } \\
\text { Kusuma }\end{array}$ & $7 / 15 / 2017$ & 53 & $40,771,000$ \\
\hline $\begin{array}{l}\text { Antariksa } \\
\text { Laksinta }\end{array}$ & $10 / 18 / 2017$ & 2 & 883000 \\
\hline Anton & $12 / 12 / 2017$ & 4 & 4498000 \\
\hline $\begin{array}{l}\text { Arindro } \\
\text { Nugroho }\end{array}$ & $8 / 3 / 2017$ & 1 & 761000 \\
\hline Astri & $12 / 19 / 2017$ & 6 & 5135000 \\
\hline $\begin{array}{l}\text { Awaludin } \\
\text { Nur Imam }\end{array}$ & $10 / 18 / 2017$ & 2 & 883000 \\
\hline Ayu & $8 / 21 / 2017$ & 4 & 13710000 \\
\hline $\begin{array}{l}\text { Cahyo Eko } \\
\text { Saputro }\end{array}$ & $7 / 27 / 2017$ & 1 & 1313000 \\
\hline $\begin{array}{l}\text { Chatarin } \\
\text { Dewi }\end{array}$ & $9 / 13 / 2017$ & 2 & 1320000 \\
\hline $\begin{array}{l}\text { Danang } \\
\text { Prayoga }\end{array}$ & $7 / 15 / 2017$ & 1 & 1780500 \\
\hline $\begin{array}{l}\text { Dani } \\
\text { Prasetyo }\end{array}$ & $6 / 16 / 2017$ & 1 & 388000 \\
\hline Darmini & $6 / 28 / 2017$ & 1 & 238000 \\
\hline Dayat & $12 / 25 / 2017$ & 1 & 2 \\
\hline
\end{tabular}

Setelah data disiapkan, langkah berikutnya adalah melakukan data selection dengan fitur recency, frequency, dan monetary. Kemudian dilanjutkan dengan data transformation. Pada data transformation dilakukan normalisasi. Seperti yang sudah dijelaskan, normalisasi merupakan proses transformasi dimana sebuah atribut numeric diskalakan dalam jarak lebih kecil Normalisasi 
dilakukan agar skala data tidak terlalu jauh. Normalisasi skor $\mathrm{z}$ (zero-mean normalization) adalah salah satu metode/teknik yang diterapkan untuk normalisasi data, dimana nilai dari atribut $\mathrm{A}$ dinormalisasi berdasarkan ratarata dan standar deviasi dari atribut A. $v$ ' adalah normalisasi nilai $v$ dari atribut $\mathrm{A}[33]$.

$$
v^{\prime}=\frac{v-\bar{A}}{\sigma A}
$$

$\bar{A}$ adalah nilai rata-rata dan $\sigma A$ adalah standar deviasi dan atribut $A$.

Tabel 4 menunjukkan hasil proses normaliasasi menggunakan zero-mean normalization.

TABEL IV

HASIL NORMALISASI

\begin{tabular}{|c|c|c|c|}
\hline $\begin{array}{c}\text { Id_pelang } \\
\text { gan }\end{array}$ & Zscore R & Zscore F & Zscore M \\
\hline 1 & 3.033 & 0.656 & 0.304 \\
\hline 2 & 0.618 & 0.758 & 10.263 \\
\hline 3 & 2.942 & 0.656 & 0.238 \\
\hline 4 & 2.306 & 0.573 & 0.303 \\
\hline 5 & 0.526 & 0.573 & 0.320 \\
\hline
\end{tabular}

Normalisasi skor $\mathrm{z}$ dan penentuan skor RFM pada data transaksi menggunakan Microsoft Excel. Setelah mendapatkan hasil, langkah berikutnya adalah pemodelan.

Tahap pemodelan atau tahap data mining menggunakan metode K-Means clustering digunakan untuk mencapai tujuan awal penelitian yaitu melakukan pengelompokan pelanggan yang kemudian akan digunakan untuk mengetahui tingkal loyalitas pelanggan dan berhubungan dengan strategi pemasaran yang tepat untuk setiap pelanggan. K-Means sebagai metode clustering yang digunakan, menuntut jumlah klaster harus ditentukan oleh pengambil keputusan. Davies bouldin index digunakan dalam penelitian ini untuk mengidentifikasi nilai $\mathrm{k}$ yang optimal [33].

$$
\begin{gathered}
D B I=\frac{1}{k}+\sum_{i=1}^{k} \max _{i \neq j}\left(R_{i, j}\right) \\
R_{i, j}=\frac{S S W_{i}+S S W_{i}}{S S B_{i, j}} \\
S S B_{i, j}=d\left(c_{i}, c_{j}\right) \\
S S W=\frac{1}{m_{i}}+\sum_{j=i}^{m_{i}} d\left(X_{j}, C_{i}\right)
\end{gathered}
$$

Nilai DBI yang kecil merupakan jumlah klaster yang baik [33]. Semakin kecil nilai DBI semakin optimal hasil klaster. RapidMiner digunakan sebagai tool untuk melakukan proses clutering dan pengujian DBI. Tabel 5 menunjukkan hasil clustering yang dilakukan dengan $\mathrm{k}=3$ menunjukkan nilai DBI yang paling baik karena menghasilkan nilai yang paling kecil [34].

TABEL V

HASIL PENGUJIAN DBI

\begin{tabular}{|c|c|}
\hline Jumlah cluster $(\mathrm{k})$ & Davies Bouldin Index \\
\hline 2 & -0.879 \\
\hline 3 & -0.941 \\
\hline 4 & -0.436 \\
\hline 5 & -0.430 \\
\hline 6 & -0.530 \\
\hline 7 & -0.537 \\
\hline 8 & -0.513 \\
\hline 9 & -0.560 \\
\hline 10 & -0.602 \\
\hline
\end{tabular}

Setelah memperoleh hasil DBI yang terbaik adalah $\mathrm{k}=3$ yaitu dengan nilai -0.941 dilanjutkan dengan proses clustering. Tabel 6 merupakan hasil pusat cluster yang diperoleh untuk setiap cluster.

TABEL VI

HASIL PUSAT CLUSTER

\begin{tabular}{|l|l|l|l|}
\hline Cluster & $\begin{array}{l}\text { Pusat } \\
\text { R }\end{array}$ & $\begin{array}{l}\text { Pusat } \\
\text { F }\end{array}$ & $\begin{array}{l}\text { Pusat } \\
\text { M }\end{array}$ \\
\hline C-1 & 0.604 & 0.844 & 0.199 \\
\hline C-2 & 0.706 & 2.743 & 2.282 \\
\hline C-3 & 0.267 & 0.531 & 0.272 \\
\hline
\end{tabular}

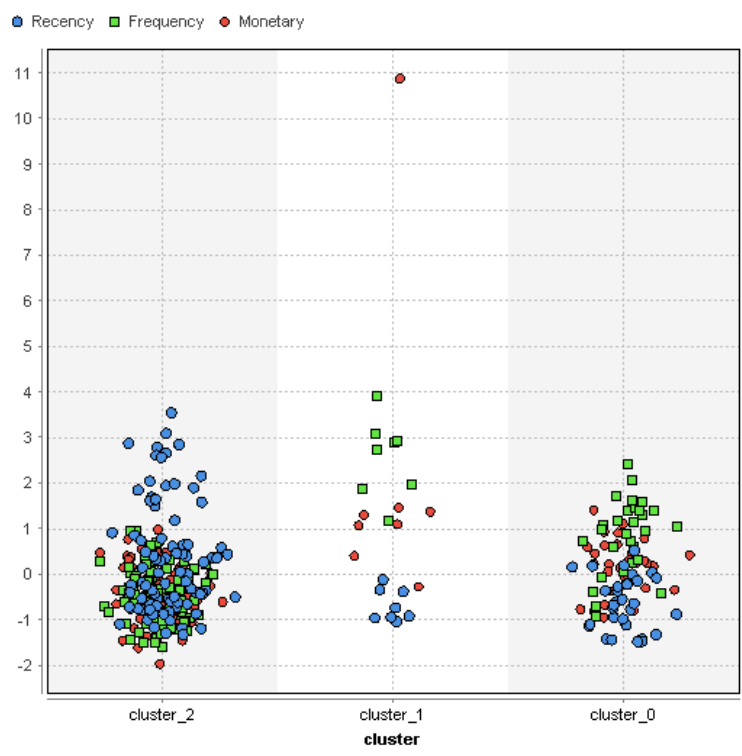

Gambar 3. Chart hasil proses clustering dengan atribut RFM

Gambar 3 menunjukkan titik persebaran setiap data yang dihasilkan dari proses clustering. Setiap cluster memiliki karakteristik yang berbeda-beda. Titik berwarna biru menunjukkan variabel monetary, titik hijau adalah variabel frequency dan titik merah untuk variabel monetary. 
Cluster 3 (cluster_2) menjadi kelompok yang memiliki titik data terbanyak dibanding dua cluster lainnya. Kemudian titik warna dalam cluster 3 terlihat berdekatan karena adanya kemiripan nilai RFM. Hasil proses clustering ditunjukkan pada Tabel 7.

TABEL VII

HASIL SEGMENTASI PELANGGAN BERDASARKAN RFM

\begin{tabular}{|l|l|l|l|l|l|}
\hline $\begin{array}{l}\text { Clust } \\
\text { er }\end{array}$ & $\begin{array}{l}\text { Jumlah } \\
\text { pelangg } \\
\text { an }\end{array}$ & $\begin{array}{l}\text { Rata-rata } \\
\mathrm{R}\end{array}$ & $\begin{array}{l}\text { Rata-rata } \\
\mathrm{F}\end{array}$ & $\begin{array}{l}\text { Rata- } \\
\text { rata M }\end{array}$ & $\begin{array}{l}\text { Skor } \\
\text { RFM }\end{array}$ \\
\hline C-1 & 30 & 0.60432 & 0.84352 & 0.19899 & $\begin{array}{l}245- \\
341\end{array}$ \\
\hline C-2 & 8 & 0.70618 & 2.743035 & $\begin{array}{l}2.28222 \\
49\end{array}$ & $\begin{array}{l}432- \\
545\end{array}$ \\
\hline C-3 & 89 & 0.267178 & 0.53093 & 0.27222 & $\begin{array}{l}111- \\
231\end{array}$ \\
\hline
\end{tabular}

Dari 127 data pelanggan, setelah melalui proses clustering diperoleh tiga cluster dengan karakteristiknya masing-masing. Pengujian jumlah cluster dilakukan menggunakan davies bouldin index untuk hasil yang optimal. Cluster pertama terdiri dari 30 pelanggan yang termasuk dalam kelompok typical customer dengan skor RFM antara 245-341. Cluster kedua terdiri dari 8 pelanggan yang termasuk dalam kelompok superstar dengan skor RFM antara 432-545 dan cluster tiga merupakan kelompok dengan value terendah yaitu antara 111-231 yang masuk ke dalam kategori dormant customer.

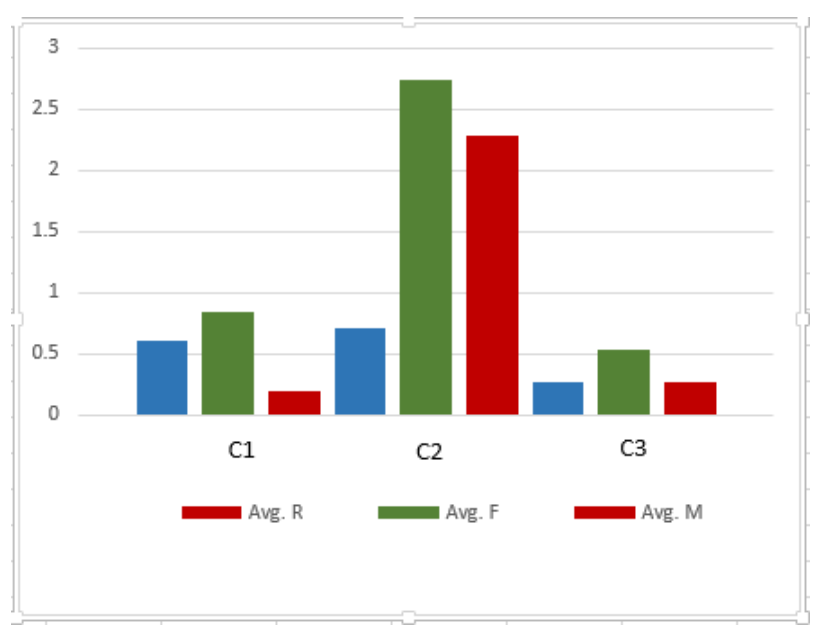

Gambar 4. Grafik Hasil Clustering

Pada Gambar 4 menunjukkan bahwa cluster 2 (C2) merupakan cluster dengan nilai RFM tertinggi. Pelanggan pada cluster ini adalah pelanggan yang paling sering melakukan transaski dengan jumlah uang yang dikeluarkan paling banyak dibandingkan dua cluster lainnya. Cluster 3 merupakan kelompok dengan nilai RFM terendah. Pelanggan pada cluster ini 1-2 kali melakukan transaksi dengan jumlah uang yang dikeluarkan tidak banyak.
Kemudian grafik cluster 1 memiliki nilai $\mathrm{R}$ dan $\mathrm{F}$ di atas cluster 3, namun dengan nilai $\mathrm{M}$ di bawah cluster 3 .

Setelah memperoleh hasil cluster melalui proses clustering dengan algoritma K-Means, tahap berikutnya adalah melakukan pengujian atau evaluasi. Tahap ini bertujuan untuk menguji hasil cluster sudah optimal atau belum. Pengujian dilakukan sebanyak dua kali, yaitu dengan global silhouette dan variance.

Pengujian silhouette dilakukan terhadap data transaksi yang sudah dikumpulkan, yaitu periode 1 Juni sampai dengan 31 Desember 2017. Pengujian dilakukan dengan masukan tiga cluster dan dihitung menggunakan persamaan silhouette, hasilnya sebesar 0.2167 . Hasil menunjukkan nilai positif, sehingga dapat dikatakan proses clustering berjalan dengan baik. Dapat disimpulkan bahwa hasil yang positif menunjukkan bahwa jarak rata-rata antar objek dalam cluster yang sama $(b(i))$ lebih kecil disbanding jarak ratarata antar objek dengan objek yang ada di cluster lain $(a(i))$. Masing-masing pelanggan berapa pada cluster yang tepat.

Pengujian kedua dengan evaluasi variance yang digunakan untuk menguji kualitas cluster yang terbentuk. Cluster yang baik adalah cluster yang memiliki nilai jarak mendekati 0 dalam cluster. Hal ini menunjukkan kemiripan nilai data yang dekat. Pada proses pembentukan tiga cluster, menunjukkan hasil evaluasi variance sebesar 1.326. Nilai variance menunjukkan angka yang mendekati 0. Sehingga dapat disimpulkan pembentukan tiga cluster memiliki kemiripan nilai data yang dekat untuk anggota setiap cluster. Hasil dua pengujian tersebut ditunjukkan pada Tabel 8.

TABEL VIII

HASIL PENGUJIAN

\begin{tabular}{|c|c|c|}
\hline \multirow{2}{*}{$\begin{array}{l}\text { Jumlah } \text { cluster } \\
(n)\end{array}$} & \multicolumn{2}{|c|}{ Evaluasi } \\
\cline { 2 - 3 } & Global Silhouette & Variance \\
\hline 3 & 0.2167 & 1.326 \\
\hline
\end{tabular}

\section{KESIMPULAN}

Tujuan utama penelitian ini adalah segmentasi pelanggan dan mengukur kesetiaan mereka terhadap sebuah produk UKM dengan mengkombinasikan model RFM dan teknik clustering menggunakan metode K-Means. Model RFM yang terdiri dari recency, frequency dan monetary digunakan sebagai variabel/atribut data yang digunakan untuk proses clustering. Untuk menemukan jumlah cluster yang paling optimal dilakukan perhitungan menggunakan davies boulding index. Hasilnya terdapat 3 cluster dengan karakteristiknya masing-masing. Cluster pertama dengan 30 pelanggan masuk ke dalam kategori typical customers. Cluster kedua terdiri dari 8 pelanggan masuk ke dalam kategoru superstar. Kemudian 89 pelanggan termasuk dalam kategori dormant customer. Kemudian pengujian dilakukan menggunakan global silhouette dan variance. Hasilnya menunjukkan bahwa data di setiap cluster berada 
pada cluster yang tepat dan memiliki kemiripan yang dekat. Aplikasi model RFM dan teknik clustering khususnya algoritma K-Means, dapat membantu mengidentifiasi pelanggan dengan nilai tinggi dan berpotensi memberi keuntungan serta dapat membantu dalam merancang strategi pemasaran yang tepat untuk ketiga cluster yang terbentuk.

\section{DAFTAR PUSTAKA}

[1] H. Zhao and C. He, "Objective cluster analysis in value-based customer segmentation method," Proc. - 2009 2nd Int. Work. Knowl. Discov. Data Mining, WKKD 2009, pp. 484-487, 2009.

[2] W. Bi, M. Cai, M. Liu, and G. Li, "A Big Data Clustering Algorithm for Mitigating the Risk of Customer Churn," IEEE Trans. Ind. Informatics, vol. 12, no. 3, pp. 1270-1281, 2016.

[3] Y. Chen, G. Zhang, D. Hu, and S. Wang, "Customer Segmentation in Customer Relationship Management Based on Data Mining," vol. 207, pp. 288-293, 2006.

[4] I. Soesanti, "Web-Based Monitoring System on the Production Process of Yogyakarta Batik Industry," J. Theor. Appl. Inf Technol., vol. 87, no. 1, pp. 146-152, 2016.

[5] Y. Luo, Q. R. Cai, H. X. Xi, Y. J. Liu, and Z. M. Yu, "Telecom customer segmentation with K-means clustering," ICCSE 2012 Proc. 2012 7th Int. Conf. Comput. Sci. Educ., no. Iccse, pp. 648651, 2012.

[6] D. Zheng, "Application of silence customer segmentation in securities industry based on fuzzy cluster algorithm," J. Inf. Comput. Sci., vol. 10, no. 13, pp. 4337-4347, 2013.

[7] R. J. Kuo, S. H. Lin, and Z.-Y. Chen, "Integration of Particle Swarm Optimization and Immune Genetic Algorithm-Based Dynamic Clustering for Customer Clustering," Int. J. Artif. Intell. Tools, vol. 24, no. 5, p. 1550019, 2015.

[8] W. Li, "Modified K-Means Clustering Algorithm," 2008 Congr Image Signal Process., pp. 618-621, 2008.

[9] N. Kurinjivendhan and K. Thangadurai, "Modified k-means algorithm and genetic approach for cluster optimization," Proc. 2016 Int. Conf. Data Min. Adv. Comput. SAPIENCE 2016, pp. 5356, 2016.

[10] M. K. Algorithm and B. D. Clustering, "IBAIS University," 2015.

[11] A. K. Jain, "Data clustering: 50 years beyond K-means," Pattern Recognit. Lett., vol. 31, no. 8, pp. 651-666, 2010.

[12] J. Wei, S. Lin, and H. Wu, "A review of the application of RFM model," African J. Bus. Manag., vol. 4, no. 19, pp. 4199-4206, 2010.

[13] Y. J. Lee, "Privacy-preserving Data Mining for Personalized Marketing," Int. J. Comput. Commun. Networks, vol. 4, no. 1, pp. $1-9,2014$.

[14] A. X. Yang, "How to develop new approaches to RFM segmentation," J. Targeting, Meas. Anal. Mark., vol. 13, no. 1, pp. $50-60,2004$

[15] C. Wang, "Robust Segmentation for the Service Industry Using Kernel Induced Fuzzy Clustering Techniques," Proc. 2009 IEEE IEEM, pp. 2197-2201, 2009.

[16] R. Ait Daoud, A. Amine, B. Bouikhalene, and R. Lbibb, "Combining RFM model and clustering techniques for customer value analysis of a company selling online," Proc. IEEE/ACS Int. Conf. Comput. Syst. Appl. AICCSA, vol. 2016-July, 2016.

[17] C. Cheng and Y. Chen, "Expert Systems with Applications Classifying the segmentation of customer value via RFM model and RS theory," Expert Syst. Appl., vol. 36, no. 3, pp. 4176-4184, 2009.

[18] S. M. S. Hosseini, A. Maleki, and M. R. Gholamian, "Cluster analysis using data mining approach to develop CRM methodology to assess the customer loyalty," Expert Syst. Appl., vol. 37, no. 7, pp. 5259-5264, 2010

[19] P. Chapman et al., "Crisp-Dm 1.0," Cris. Consort., p. 76, 2000.

[20] A. Brandão, E. Pereira, F. Portela, M. F. Santos, A. Abelha, and J. Machado, "Managing Voluntary Interruption of Pregnancy Using Data Mining," Procedia Technol., vol. 16, pp. 1297-1306, 2014.

[21] S.-C. Huang, E.-C. Chang, and H.-H. Wu, "A case study of applying data mining techniques in an outfitter's customer value analysis," Expert Syst. Appl., vol. 36, no. 3, pp. 5909-5915, 2009.

[22] J. Zhao, W. Zhang, and Y. Liu, "Improved K-Means cluste algorithm in telecommunications enterprises customer segmentation," Proc. 2010 IEEE Int. Conf. Inf. Theory Inf. Secur. ICITIS 2010, pp. 167-169, 2010.

[23] D. Birant, "Data Mining Using RFM Analysis," in KnowledgeOriented Applications in Data Mining, Turkey: KImito Funatso, 2011, pp. 91-108.

[24] I. Pranata and G. Skinner, "Segmenting and targeting customers through clusters selection \& analysis," ICACSIS 2015 - 2015 Int. Conf. Adv. Comput. Sci. Inf. Syst. Proc., pp. 303-308, 2016.

[25] K. Tsiptsis, Data Mining Tehniques in CRM: Inside Customer Segmentation. 2010.

[26] S. Singh Raghuwanshi and P. Arya, "Comparison of K-means and Modified K-mean algorithms for Large Data-set," Int. J. Comput. Commun. Netw., vol. 1, no. 3, pp. 106-110, 2012.

[27] R. V. Singh and M. P. S. Bhatia, "Data clustering with modified Kmeans algorithm," Int. Conf. Recent Trends Inf. Technol. ICRTIT 2011, pp. 717-721, 2011.

[28] B. Yi, F. Yang, H. Qiao, and C. Xu, "An improved initialization center algorithm for K-means clustering," 2010 Int. Conf. Comput. Intell. Softw. Eng. CiSE 2010, no. 1, pp. 1-4, 2010.

[29] T. Widiyaningtyas, M. Indra, W. Prabowo, and M. A. M. Pratama, "Implementation of K-Means Clustering Method to Distribution of High School Teachers," no. September, pp. 19-21, 2017.

[30] K. Singh, D. Malik, and N. Sharma, "Evolving limitations in Kmeans algorithm in data mining and their removal," IJCEM Int. $J$. Comput. Eng. Manag. ISSN, vol. 12, no. April, pp. 2230-7893, 2011.

[31] P. J. Rousseeuw, "Silhouettes: A graphical aid to the interpretation and validation of cluster analysis," J. Comput. Appl. Math., vol. 20 no. C, pp. 53-65, 1987.

[32] T. Handhayani, I. Wasito, M. Sadikin, and A. I. K-means, "Kernel Based Integration of Gene Expression and DNA Copy Number," pp. 978-979, 2013.

[33] T. Hardiani, S. Sulistyo, and R. Hartanto, "Segmentasi Nasabah Tabungan Menggunakan Model RFM ( Recency, Frequency, Monetary ) dan K-Means Pada Lembaga Keuangan Mikro ISBN 979-26-0280-1 ISBN : 979-26-0280-1," Semin. Nas. Teknol. Inf. dan Komun. Terap., no. May 2017, pp. 463-468, 2015.

[34] H. Qiao and B. Edwards, "A data clustering tool with cluster validity indices," ICC2009 - Int. Conf. Comput. Eng. Sci. Inf., vol. 1, no. 2, pp. 303-309, 2009. 